\title{
Paradoxes of Contemporary Anthropology
}

\author{
Martin Soukup \\ Michaela Konopíková
}

\section{Doi:10.5901/mjss.2013.v4n10p457}

\begin{abstract}
The main objective of the study is to analyze the state and position of contemporary anthropology. It is based on the examination of the selected anthropological textbooks, which are evaluated taking into consideration currently discussed anthropological issues. Our goal is to provide a contribution to the ongoing debate on the norms and forms of contemporary anthropology.
\end{abstract}

\section{Intoduction}

The concept and tradition of social and cultural anthropology are closely linked with the manner anthropology is taught at an undergraduate level (Mills 2011). Taking into account the content of textbooks, we are posing a question on what the significant features of contemporary anthropology are. This study offers one of the many possible answers. At this point, we believe it is important to note that we have identified a certain version of a "culture gap" since the teaching materials lag behind the actual state of the discipline. The textbooks chosen for the analysis are Kottak (2011), Haviland et al (2011), Schultz and Lavenda (2005) and Heider (2004).

The same issue was questioned by Rabinow, Marcus and Rees. Together with Faubion, he dealt with the matter by striving to answer questions about the forms, norms, methods and mission of contemporary anthropology. They agreed that the publication Writing Culture was a milestone in this pursuit. Its contributors critically evaluated the classic conception and methodologies of socio-cultural anthropology (Clifford \& Marcus, 2010). The participants concluded that the conventional concept of anthropology was successfully challenged. However, no one has yet offered an alternative to methodological and epistemological norms and forms, which would be applicable within the training of the new generation of anthropologists (Rabinow \& Marcus \& Faubion \& Rees, 2008).

In the eighties, the traditional concept of anthropology as a discipline aimed at studying cultures in time and space was shattered. The spatial-temporal basis of the discipline was coined by its founders in the $19^{\text {th }}$ century. The representatives of so-called "classic evolutionism" were facing the same challenge as Darwin, who could not directly observe the process of biological evolution. Darwin dealt with this problem by demonstrating the diversity of species in space. Such distribution indicated evolutionary relationships. Similarly, evolution of culture was shown by its diversity in space, which represented evolutionary relationships. Like natural scientists, socio-cultural anthropologists did not have an opportunity to directly observe the evolution of culture, but were left to demonstrate it via diversity in space: a particular culture represented a particular evolutionary stage. Thus, similar to evolutionary biology and paleontology, the temporal dimension of culture was expressed through space. In other words, the design of anthropology was to be determined by its temporal-spatial character; however, the temporal axis could have actually been absent. Nothing really changed in this respect within the subsequent decades of the development of the discipline. It may be observed as significant that the basis of the discipline as an empirical domain was in the first place postulated by natural scientists (especially by Haddon, Seligman, Rivers and Boas) based on the experience derived from expeditions they carried out. These expeditions extensively focused on spatial distribution and examination of the regional varieties of cultural elements. Haddon, for instance, unequivocally proposed the zoological method in anthropology (Haddon, 1895, cf. Roldán, 1992).The transition from an extensive method (expedition) to an intensive (long-term field research) rather highlighted the requirement to study the spatially localized culture in a concrete Ethnographic present recorded and interpreted by the researcher.

Some anthropologists in the eighties made the spatio-temporal model of anthropology subject to critique since it assumed the distribution of the subject of study in space as a phenomenon independent on the temporal axis. A sound critique of an absenting historical aspect in anthropology was articulated by Eric Wolf (1982) and Johannes Fabian 
(1983). The attempts for retemporalization of anthropological discourse also contributed to the destruction of the spatial axis. Nowadays, these tendencies are reflected in an interdisciplinary research, which takes anthropology as one of many sources, which include STS, media studies and women's studies. Recently established disciplines not only define a new subject of study, but they also develop new methodological approaches, which are eventually reflected in the traditional socio-cultural anthropological studies. To sum up, contemporary anthropology does not deal anymore with the model of culture, which is defined as a spatially bordered unit, isolated to a certain extent.

\subsection{What the textbooks say}

The differences between British and American cultural anthropology are not only found in their choice of topics, which are accentuated by their representatives. They are also noticeable in the methods of teaching. American cultural anthropological textbooks are formalized in order to convey the terminology, system and methodology of the discipline. The structure seems to be highly conventional.

Unlike American teaching materials, the British textbooks are not formalized to such a point; at least they are not so much standardized. We can count among influential textbooks a teaching material by Firth (1958) and Pocock (1961). Yet the explanation of the subject and concepts of anthropology is not carried out systematically by either of them. A similar style of the introductory text in anthropology was chosen by Fox (1973), who amended an autobiographical dimension. Another famous text structurally similar to American textbooks was written in the mid-sixties by Beattie (1966). A glimpse into the French and German introductory textbooks and overview materials reveals their apparent similarity with American (cf. e.g. Haller, 2005; Laburthe \& Tolra \& Warnier, 1997).

For our purpose we have selected four textbooks written by renowned authors. These are texts by Kottak (2011), Haviland et al. (2004), Schultz and Lavenda (2005) and Heider (2004). All of them are teaching materials published after 2000. In the mainstream publications we habitually find a statement that anthropology is a comparative holistic discipline, which studies cultures in time and space. The aim of the study is thus to find out whether such a definition adequately reflects the true state of the discipline.

The "mainstream textbooks" stick to the established structure, which was smartly summarized by Eller, who also attempted to present an alternative model since he feels frustrated from the textbooks abiding conformity and unification,

"All of them naturally include a discussion of the concept of culture and its major components, like language and gender and personality. All of them present an analysis of the important areas of culture - economics, politics, kinship, and religion. However, virtually all offer at most a couple of concluding chapters on "culture change" and "the modern world" as if these matters are tangential, almost anathema, to anthropology and barely within its purview"(Eller, 2009, xvii).

\section{Paradox 1: Culture}

"Anthropology is the study of different ways of life, both past and present. This field, as we know it today, is a relatively new discipline, emerging only in the late 19th and early 20th centuries as an aid to, and a reaction against, European colonialism. Above all, it is comparative and cross-cultural, combining elements from biology, linguistics, sociology, psychology, and history into a grand synthesizing endeavor".

Heider (2004)

The first definition of culture was produced by English anthropologist Edward Tylor in 1871. His rather lengthy definition occupied a spot in anthropological textbooks so persistently that it has become the most cited definition ever ${ }^{1}$. Cronk analysed twenty textbooks used in introductory anthropology courses and came to the conclusion that more than 75 percent contain a definition of culture that is basically identical with Tylor's (Cronk 1999, p. 4). The term "culture" stood as a principal term of anthropology aiming to study groups of people in time and space. Until the eighties, the term culture constituted the core of anthropology to be analysed in the following decades. In the collection of essays Writing Culture: The Poetics and Politics of Ethnography the focus was shifted from studies of culture to existing ethnographic texts, which were subject to semantic analysis. "They see culture as composed of seriously contested codes and representations; they assume that the poetic and the political are inseparable ..." (Clifford, 2010, p. 2). The production of text and rhetoric only highlights the artificially constructed nature of cultural statements. Embedded in interpretation, his

${ }^{1}$ Tylor's famous definitiv states that,"Culture, or civilization, taken in its broad, ethnographic sense, is that complex whole which includes knowledge, belief, art, morals, law, custom, and any other capabilities and habits acquired by man as a member of society." (Tylor 1871 : 1). 
presentations limit reinterpretation (Crapanzano 2010: 52). The transition from the studies of culture to textual analysis generated numerous responses. The collection After Writing Culture can be counted as one of them. The first chapter The Road from Santa Fe (the place where the seminar of contributors to the collection Writing Culture was held) calls upon the new way of ethnographic writing. It also seeks to answer who, what, how and why we should aim to represent. The authors examine issues such as reverberations of modernist epistemologies of the subject and the possible existence of shared or universal external references -- which can make the cultural "translation" viable -- the questions of authorial style and the nature and status of models which may be deemed effective in an applied setting (James \& Hockey \& Dawson, 1997).

It would be possible to offer a consistent account on culture as a subject in case the traditional approach, structure and organization would be maintained. However, as we noted, this trend is being gradually abandoned. The twist has to do with the inclination to narrative strategies, pluralist discourses and general perception of anthropology as a kind of a narration constituted within the process of interaction and followed by "translation" between the member of a culture and anthropologist. The rejection of the word culture can be traced to the work of Appadurai. Instead, he suggests the word cultural be used. According to him, the term culture implies substantialization implying, like the word race, the notion to treat social groups like cultures (Appadurai, 2005). On the other hand, the word cultural assumes certain plurality and heterogeneity; as such, it seems to be a more appropriate tool for examination of particular segments of a deterritorialized, culturally hybridized world inhabited by diasporas.

The traditional concept of culture provoked speculations aiming to identify what makes us different from each other instead of trying to determine what we share in common. The necessity to reconsider this approach was mentioned by Gupta and Fergusson (1992) who proposed cultural and social change to be considered as a matter of rethinking difference through connection, since spaces have always been hierarchically interconnected instead of naturally disconnected. The Fiji anthropologist of Tongan descent Epeli Hau'ofa suggested such a reconceptualization using the islands in the Pacific Ocean as an example. The conventional narration depicts these islands as small, poor isolated states scattered in the waters of an enormous ocean. Nevertheless, this geographically determined definition primarily takes into account the area, and does not reflect on the islands' rich cultural history and the fact that the people inhabiting these territories not only do consider their universe the relatively small islands, but also the ocean which surrounds them. Hence, instead of thinking of "islands in a far sea," we should reflect on it as "a sea of islands". In fact, this approach accentuates the totality of relations instead of smallness and distance (Hau'ofa, 1994). The word "culture" as a cornerstone of anthropology would deserve a similar reconceptualization.

\section{Paradox 2: Comparative method}

"The postmodern, writing culture project has stifled young ethnographers. It has become a source of ideological support for identity politics. Most importantly, this project denies the possibility of a cross-cultural, comparative anthropology." Adam Kuper (1999)

Haviland's textbook states that "ethnographies provide the information used to make systematic comparisons among cultures all across the world. Known as ethnology, such cross-cultural research allows anthropologists to develop anthropological theories that help explain why certain important differences or similarities occur among groups" (Haviland \& Prins \& McBride \& Walrath, 2011, p. 12). Similar statements can be also found in the texts by Heider (2004), Kottak (2011) and Schultz and Lavenda (2005). Schultz and Lavenda add that a comparative approach is, besides holism, the main characteristic of anthropology. They define comparation as, "A characteristic of the anthropological perspective that requires anthropologists to consider similarities and differences in as wide a range of human societies as possible before generalizing about human nature, human society, or the human past"(Schultz \& Lavenda, 2005, p. 3). Another frequent term in the anthropological texts is the doctrine of cultural relativism. It is a non-evaluative approach involving some specific methodological claims an anthropologist should engage in order to understand a concrete culture within its own terms and from the perspective of The Other. Comparative method and cultural relativism as one of the central pillars of the discipline are mutually contradictory.

Classic anthropology dealt with the discrepancy between cultural relativism and comparative method using various gnoseologic tools and concepts. A special attention was paid to emic and ethic perspective. With a certain degree of simplification it is possible to conclude that emic perspective corresponds to cultural relativism as an ethnographer obtains a specific set of data on a culture, and records as they were presented from the perspective of the members of a culture. An ethic approach allows for comparative method owing to the application of concepts developed in anthropology. A specific analytical tool enabling comparative approach was drawn up by Murdock, who introduced a 
conception of cultural universals. Universals denote a kind of cultural element present in all known cultures. This concept permits the construction of typologies as a basis for comparative analysis. Murdock though pointed out that,"they are similarities in classification, not in content " (Murdock, 1965: 90). A few comparative researches were conducted in the twentieth century, for example Coordinated Investigation of Micronesian Anthropology (1947-1949), Six Cultures Project (1954-1956) and Puerto Rico Project (1947-1949).

Comparative approach is based on an evaluation of morphology, structure or function of cultural elements. The examination of morphology, structure and function can be traced back to natural sciences. Later on, it was adopted by social sciences, especially due to the effort of Herbert Spencer (Andreski, 1971). Morphology in particular forms a basis of modern biological classification as it was laid out by Carl Linnaeus in the $18^{\text {th }}$ century. The study of objects (how they appear to us) and the Cartesian coordinate system (measurability of objects in time and space) allow for a cognitive seizing of the world. Anna Tsing (2005) goes even further, noting that as European hegemony grew, European knowledge increasingly directed global programs. She also adds that scholars of colonialism have pointed to the texts of eighteenth- and nineteenth- century European botanists, gathering plants in non-European locales, as models for imperial consciousness. It allowed for the classification of "Otherness," hence otherness became a part of order. Consequently, after the deconstruction of the concept of culture as an entity localized in space and time, the comparative method is not applicable in contemporary anthropology. However, the cited teaching materials continue to declare, that anthropology is a comparative discipline. It goes without saying that classical anthropology has made many achievements engaging comparative approach. The question to be answered is if (and how) contemporary anthropology can produce a knowledge basis using comparative method.

\section{Paradox 3: Isomorphism of place, space and culture}

"What does it mean, at the end of the twentieth century, to speak ... of a "native land"? What processes rather than essences are involved in present experiences of cultural identity?"

James Clifford (1996)

Traditional anthropology did not only employ the construct of culture; it placed the construction in a bordered territory. When talking about Lele people we have in mind the Congo (formerly Zaire). Yurok people are placed in California. New Guinea is inhabited by Mae Enga people for us, just like it was for Mary Douglas (Douglas, 2007). She conducted her doctoral research among the Lele people of the Kasai River (the book later published bears the same name - The Lele of the Kasai), although she documented Lele migrating a few hundreds of kilometres farther to Kinshasa (Douglas, 1999). The notion of culture as a geographically localized unit even more highlighted its distinctive nature because it asserts that these clearly defined territories are home to easily distinguishable cultures.

The teaching materials in anthropology usually contain maps with marked territory inhabited by the culture/ethnic group discussed. The graphic representation hence helps fix the isomorphic nature of culture and space (cf. Heider, 2004). The isomorphy is obvious in ethnoprofiles presented in the textbook by Schultz and Lavenda. They provide basic information on the locality, nation, population, livelihood and a famous ethnographic monography on the particular culture. In the ethnoprofiles the authors refer to a concrete spot in the map, they define the space inhabited by a culture, and via a recommended monography determine the ethnographic present, which the profile refers to (Schultz \& Lavenda 2005).

The African continent in the process of decolonization went through defragmentation of space. Europeans parcelled Africa out, and the pressure to reconfigure the image of the continent went hand in hand with this process. The orthogonal organization of space contributed to the annihilation of native cultures, which Lévi-Strauss observed among Bororo people in the state of Matto Grosso (Lévi-Strauss, 1973). Europeans described Africa as a primitive savage wilderness. Therefore, it was the objective of anthropologists, adventurers and photographers to map it out again.

"In a few decades, Europeans seemed willfully to forget all that they had learned about Africa since the fifteenth century. They deculturated Kongo in order to acculturate... Africans to the new entity they had created named the Congo. While anthropologists later assumed that Africans "evolved" from tribes to kingdoms, the reverse was in fact true-Europeans destroyed the kingdom of Kongo and created the Congo tribes as part of their divide-and-rule policy" Mirzoeff 1999, p. 134

The local nations had to adapt to the new political reality and cultural practice. These changes took place within the territory, which was created violently and artificially, hence it did not pay attention to the particular ethnic groups and 
their dislocation in space. The attempts to imagine the world as a successive chain of cultures is being threatened by the existence of diasporas, the emergence of transnationalism and the mass migration of populations.

Yet in the eighties, the question of space was not often frequented as in anthropological theory (Gupta \& Fergusson 1992). In a famous article Beyond "Culture": Space, Identity, and the Politics of Difference, they argue that the renewed interest in theorizing space and notions as surveillance, borderlines, simulacra, deterritorialization marginality ... forces us to reevaluate central analytic concepts such as "culture" and the idea of "cultural difference" (Gupta \& Fergusson, 1992, p. 6). Moreover, the assumed isomorphism of space, place and culture creates significant problems in dealing with the existence of migrants and people inhabiting the borders. The issue of cultural differences within a locality, subcultures, is followed with the matter of contemporary postcolonial reality and the emergence of hybrid cultures of postcoloniality. Finally, there is the question of cultural transformation situated within interconnected spaces, which forms an opposite to the traditional anthropological notion of inherently fragmented space (Gupta \& Fergusson, 1992). These questions also force us to search for a new attitude to the issue of identity, which is considered besides culture to be the crucial area of research like migration research and hybrid identities are.

The idea of culture created, reproduced and preserved by a specific group of people sharing a specific space, which can be easily examined within its borders upon a visit or fieldwork, has been subject to critique. In this context we should ask about a constitutive element of anthropology itself - fieldwork, as the voices calling for reevaluation of the traditional standpoints echo even in the realm of the field. At present, it is not possible to outline a complete picture merely from the local perspective since "local" is also a product of a dialectical relationship between the local situation and global reality. The geographic localization is not sufficient anymore. The field nowadays consists of several localities that constitute a single coherent playground of field research. The trends bound to the era of modernity and contemporary postmodern reality contribute to the deeper and broader deterritorialization and transformation of identities. For instance, the original inhabitants of Maghreb living in francophone European countries or inhabitants of the UK of Asian descent represent a couple of the waves of migration.

Contemporary anthropology strives to overcome the traditional spatial and cultural division, which created its basis in the past. One of the reasons for this is that deterritorialization destabilized the formerly fixed ideas of "us" and the "others" -- hence, it has opened up space for a more thorough reflection of the world. The distance between the rich in London and in Bombay can be much shorter than the distance between different classes in "the same" city. Physical location, for so long the only grid on which cultural difference could be mapped, needs to be replaced by multiple grids that enable us to see that connections vary considerably according to social and biological factors (Gupta \& Fergusson, 1992, p. 20).

\section{Paradox 4: Myth of holism}

"For many students, AN-101 is the first and last place they encounter holism in anthropology." Bradd Shore (1999)

Karl Heider regards holism a central feature of ethnography: "holism has an ancient and honorable ancestry in anthropology"(Heider, 1970, p. 3). He turns to Malinowski, who in Argonauts of the Western Pacific noted that anthropology deliberately deals with "the totality of all social, cultural and psychological aspects of the community"(Malinowski, 1922, xvi). This audacious statement according to Heider does not reflect reality. Despite the complicated position holism occupies in anthropology, an anthropologist must do his best to accomplish it. Heider pursues the idea combining visual and textual means of representation. However, he believes it is not possible to slavishly follow an apel "whole people in whole acts"(Heider, 2006, p. 6) because no achievements would come out from a camera recorder turned on for the whole day capturing the village. The call for representation of "whole bodies," "whole people," "whole interactions," and "whole acts" resists both an eye of the camera and capturing in words (cf. Heider, 2006, p. 5-6).

Bradd Shore is convinced that the notion of holism bears the stamp of the birth and expansion of anthropology as an interdisciplinary field of study, whose founders were originally educated in natural sciences (Boas, Malinowski), psychology (Fortes, Rivers, White), philosophy (Lévi-Strauss, Lévy-Bruhl) and literary theory (Benedict). Because anthropology drew from the traditions of diverse disciplines, the adopted concepts and theories were tested and cultivated within a multicultural point of view. The study of cultures centered on isolated and "simple" societies; this fact led to the premise that it is possible to study them in a holistic way. Moreover, the above quoted Tylor's definition pointed out the direction since it was introduced: "Culture, or civilization, taken in its broad, ethnographic sense, is that complex whole ... (Tylor, 1871, p.1, underlined by MK\&MS). The traditional anthropological premise is that an anthropologist 
carries out field research alone; therefore he/she has to be interdisciplinary competent. As Shore points out, this effort requires an anthropologist to be an intellectual Jack-of-all-trades. Robert Borofski noted, however, that the proclaimed interdisciplinary collaboration is a myth. Based on the research in American Anthropologist, he proved that only 9.5 percent of studies contain aspects of interdisciplinary approach (Borofski ${ }_{2} 2002$ ). Nowadays, the trend to study complex societies due to the loss of the traditional subject of study is on the rise. The application of holism is almost impossible. "Do you want to say really, really, counts there is the Frenchness? If so, you'd look ridiculous" (Rabinow \& Marcus \& Faubion \& Rees, 2008, p. 110).

\section{Paradox 5: Loss of the subject}

"... life is with people-no other way is conceivable". --David Riesman, foreword to "Return to Laughter"

Sociocultural anthropology can hardly deny its connection to colonialism. Taking into account the circumstances of its origin, the historical era it was established, the predicate "imperialistic discipline" seems more and undeniable fact than exaggerated hyperbolic statement. Territorial expansion of European states facilitated on one hand access to distant localities. On the other hand, the necessity to effectively administer the subordinated territories led to a call for information on the unknown Other, which was to be first identified and then civilized. The word "civilization" expressed a specific set of skills and modes of behaviour inherent to a member of civilization, which, according to the former discourse, differed from the members of "primitive" societies. The moment the members of Western civilization felt the development as complete, they placed themselves on an imaginary pedestal, turned outside, and with the notion of superiority started disseminating their values to other parts of world.

The platform for the relationship between anthropologist and the examined object, or the society of "Others," was power. The relationship was uneven, as it is traceable in the outputs of fieldwork - anthropological texts, monographs, anthologies or published field notes and diaries which are the cherry on top of a cake and at the same time proof of an author's presence in the field. As Talal Asad (1973, p.17) notes, "Anthropological understanding is overwhelmingly objectified in European languages that it is most easily accommodated to the mode of life, and hence to the rationality, of the world power which the West represents." At the beginning of the twentieth century, anthropologists commonly got to the places of their research only after they were granted the necessary permits by colonial administrations. They took notes in the field, and later in the silence of their study rooms they worked on translating, selecting and interpreting them to prepare them for publishing. These pictures of the world are not creations of the authors of the particular publications; they represent images controlling western imagination (Achebe, 2001, p. 23). Anyway, a few decades earlier it was not necessary to even pay a visit to discussed places. A comparative study on mythology and religion by Scottish anthropologist James Frazer was based on the material collected by Christian missionaries. When Laura Bohannan was heading off for field research in Nigeria, an anthropology professor gave her valuable advice: "Enjoy yourself, and never, never be an embarrassment to the administration"(Bowen, 1964, p. 4). She noted a few pages later in her field work notes that she eventually did become one.

The decay of colonial empires brought about an annoying development anthropologists had to deal with: they were challenged to choose a new subject of study. The circumstances of the decolonising process shed light on the fact that the world could no longer be conceptualized as "us" and "them". The denial of the concept of "them" or The Other basically signified loss of the subject, which had to be found again. This issue is partly resolved in an attempt of anthropology to turn towards modern societies; yet on the other hand, a kind of "closing up the circle" is happening. The people we used to call the "other" are now a part of our present, as post-colonial studies succinctly point out.

A peek into the textbooks regarding the anthropological subject reveals a definition somehow similar to the following: "...Modern anthropologists are concerned with studying all human societies, doing research in urban and rural settings around the world and among members of all societies, including their own" (Schultz \& Lavenda, 2005, p. 8). Analogous words can be found in Kottak's textbook (2011, p. 5). Many authors of textbooks while defining the subject of study note that cultural anthropology studies cultures and societies in a spatio-temporal dimension; a special emphasis is placed on the non-western societies. The change of the discipline is evident. The publications from the first half of the twentieth century reflect the feeling of exclusivity anthropologists held.

Such a determination of the subject proved to be anachronistic already at that time. The alliterate societies due to long-term and intensive contact with Western society went through a dramatic change and sometimes even ceased to exist. The opening of Malinowski's book The Argonauts of the Western Pacific seems to be very significant in respect to what we discussed above. "Ethnology is in the sadly ludicrous, not to say tragic, position, that at the very moment when it 
begins to put its workshop in order, to forge its proper tools, to start ready for work on its appointed task, the material of its study melts away with hopeless rapidity."(Malinowski, 1922, p. xv).

Since the sixties a shift happened in sociocultural anthropology that manifested in several areas. The increasing tendency towards reflexivity arising with the period of decolonization became problematic to the extent that the new issue labelled as crisis of representation was brought up. Analyses of colonial situations revealed surprising information about the circumstances of classic field researches and their outputs as they were presented by their authors (Gellner, 1998; Stocking, 1991; Asad, 1973). The textbooks almost all avoid mentioning this transformation of the discipline.

Anthropology as a scientific discipline developed in an era that strictly divided the world into two halves. One was populated by us and the other was reserved for the people who we made the subject of examination. The distinction is not valid anymore, owing to the existence of transnational flows, globalization movements and migration waves. Generally speaking, the "others" are not to be found exclusively in Melanesia, central Africa or in Southeast Asia.

\section{Conclusion}

The main objective of our study was to present the results of an analysis of the teaching materials. We concluded that the conventional definition of anthropology as stated in textbooks, i.e. anthropology is a holistic and comparative discipline aimed at the study of cultures and societies anchored in time and space, does not correspond to the contemporary state of anthropology as a discipline. Analysis of particular key words in a standard textbook definition proved that there is a necessity to reevaluate each of the categories and simultaneously reconsider methodological approaches and theoretical tools in order to ensure anthropology will maintain the potential to reflect on the current state of the world.

We identified five paradoxes of contemporary anthropology. It is defined as a holistic discipline; however, bearing in mind the subject of classical anthropological research, it fails to meet this obligation. Further on, it proclaimed a comparative approach, but the loss of the traditional subject of study makes comparation impossible, or at least very difficult. Disintegration of the spatio-temporal axis (isomorphism of place, space and culture) is, in light of current research, more than an obvious fact. The abovementioned findings imply that culture cannot stand as the central concept of the discipline. Nevertheless, the textbooks still open with question, "What is culture?"

\section{Reference}

Achebe, C. (1977). An Image of Africa: Racism in Conrad's 'Heart of Darkness. Massachusetts Review, 18(4), 782-794.

Andreski, S. (Ed.). (1971). Herbert Spencer: Structure, Function and Evolution. London: Michael Joseph.

Appadurai, A. (1996). Modernity at Large: Cultural Dimensions of Globalization. Minneapolis: University of Minnesota Press.

Asad, T. (Ed.). (1973). Anthropology \& the Colonial Encounter. Amherst: Humanity Books.

Barth, F. (Ed.). (2005). One Discipline, Four Ways: British, German, French, and American Anthropology. Chicago: University of Chicago Press.

Beattie, J. (1966). Other Cultures. London: Routledge.

Borofsky, R. (2002). The Four Subfields: Anthropologists as Mythmakers. American Anthropologist, 104(2), 463-480.

Bowen, E. (1964). Return to Laughter: An Anthropological Novel. New York: Doubleday.

Clifford, J., \& Marcus, G. (Eds.). (2010). Writing Culture: the Poetics and Politics of Ethnography. Berkeley: University of California Press.

Clifford, J. (2010). Partial Truths. In J. Clifford, \& G. Marcus, Writing Culture: the Poetics and Politics of Ethnography (Pp. 1-27). Berkeley: University of California Press.

Clifford, J. (1996). The Predicament of Culture: Twentieth-Century Ethnography, Literature, and Art. Cambridge: Harvard University Press.

Crapanzano, V. (1985). Tuhami, Portrait of a Moroccan. Chicago: University of Chicago Press.

Crapanzano, V. (2010). Hermes' Dilemma: The Masking of Subversion in Ethnographic Description. In J. Clifford, \& G. Marcus, Writing Culture: the Poetics and Politics of Ethnography (Pp. 51-76). Berkeley: University of California Press.

Cronk, L. (1999). That Complex Whole: Culture and the Evolution of Human Behavior. Boulder: Westview Press.

Douglas, M. (1963). The Lele of the Kasai. London: Oxford University Press.

Douglas, M. (1999). Implicit Meanings. London: Routledge.

Douglas, M. (2007). Purity and Danger: an Analysis of Concept of Pollution and Taboo. New York: Routledge.

Eller, J. (2009). Cultural Anthropology. London: Routledge.

Fabian, J. (1983). Time and the Other: How Anthropology Makes its Object. New York: Columbia University Press.

Firth, R. (1958). Human Types: An Introduction to Social Anthropology. New York: A Mentor Books.

Fox, R. (1973). Encounter with Anthropology. New York: Harcourt Brace Jovanovich. 
Gellner, E. (1998). Language and Solitude. Cambridge. The University of Cambridge.

Gupta, A., \& Ferguson, J. (1992). Beyond "Culture": Space, Identity, and the Politics of Difference. Cultural Anthropology, 7(1), 6-23.

Haddon, A. C. (1895). Evolution in Art. London: W. Scott.

Haller, D. (2005). Ethnologie. München: Deutscher Taschenbuch Verlag

Harris, M. (1976). History and Significance of the Emic/Etic Distinction. Annual Review of Anthropology, 5, 329-350.

Hau'ofa, E. (1994). Our sea of islands. Contemporary Pacific, 6(1), 148-161.

Haviland, W., Prins, H., McBride, B., \& Walrath, D. (2011). Cultural Anthropology: the Human Challenge. Belmont: Wadsworth/Cengage Learning.

Heider, K. (2004). Seeing Anthropology: Cultural Anthropology Through Film. Boston: Pearson.

Heider, K. (2006). Ethnographic Film. Austin: University of Texas Press, 2006.

James, A., Hockey, J, \& Dawson, A. (Eds.). (1997). After Writing Culture: Epistemology and Praxis in Contemporary Anthropology. London: Routledge.

Kottak, C. (2011). Cultural Anthropology: Appreciating Cultural Diversity. New York: McGraw-Hill.

Kuper, A. (1999). Culture: the Anthropologists' Account. Cambridge: Harvard University Press.

Laburthe-Tolra, P., \& Warnier, J-P. (1997). Ethnologie, Anthropologie. Paris: Presses Universitaires de France.

Lévi-Strauss, C. (1973) Tristes Tropiques. London: Jonathan Cape.

Malinowski, B. (1922). Argonauts of the Western Pacific. London: George Routledge and sons.

Marcus, G. (1995). Ethnography in/of the World System: The Emergence of Multi-Sited Ethnography. Annual Review of Anthropology, 24, 95-117.

Mills, D. (2011). Have We Ever Taught Anthropology? A Hidden History of Disciplinary Pedagogy. Teaching Anthropology, 1(1), $12-20$.

Mirzoeff N (1999). An Introduction to Visual Culture. London: Routledge.

Murdock, G. (1965). Culture and Society. Pittsburgh: Pittsburgh University Press.

Pocock, D. (1961). Social Anthropology. London - New York: Sheed and Ward.

Rabinow, P., Marcus, G., Faubion, J., \& Rees, T. (2008). Designs for an Anthropology of the Contemporary. Durham: Duke University Press.

Roldán, A. (1992). Looking at Anthropology from a biological point of view. A.C. Haddon's metaphors on Anthropology. History of the Human Sciences, 5(4), 21-32.

Shore, B. (1999). Strange Fate of Holism. Anthropology News, 40(9), 5-6.

Schultz, E., \& Lavenda, R. (2005). Cultural Anthropology: A Perspective on the Human Condition. New York: Cambridge University Press.

Stocking, G. (Ed.). (1991). Colonial Situations. Wisconsin: The University of Wisconsin Press.

Stocking, G. (1982). Gatekeeper to the field: E. W. P. Chinnery and Ethnography of the New Guinea Mandate. History of Anthropology Newsletter, 9(2), 3-12.

Tsing, A. (2005). Friction. An Ethnography of Global Connection. Princeton: Princeton University Press.

Tylor, E. (1871). Primitive Culture: Researches into the Development of Mythology, Philosophy, Religion, Art, and Custom. London: Murray.

Wolf, E. (1982). Europe and the People Without History. Berkeley: University of California Press. 